\title{
Development of in-house Taqman qPCR assay to detect equine herpesvirus-2 in Al-Qadisiyah city
}

\author{
M.H. Al-Saadi \\ Department of Internal and Preventive Medicine, College of Veterinary Medicine, University of Al-Qadisiyah, Al-Qadisiyah, \\ Iraq, Email: mohammed.alsaadi@qu.edu.iq
}

(Received September 6, 2019; Accepted October 1, 2019; Available online July 23, 2020)

\begin{abstract}
EHV-2 is distributed in horses globally. It is clustered within gamma-herpesvirus subfamily and percavirus genus. EHV-2 infection has two phases: latent and lytic. In the later, EHV-2 mainly associated with respiratory and genital symptoms. However, in the quiescent phase of infection, EHV-2 stay dormant in the host till viral reactivation. Our previous study has showed that EHV-2 can be harboured by equine tendons, suggesting that leukocytes possibly carrying EHV-2 for the systemic dissemination. So far, numerous PCR protocols have been performed targeting the gB gene. However, this gene is heterogenic. Therefore, there is a need to develop a quantitative diagnostic approach to detect the quiescent EHV-2 strains. To do this, Taqman qPCR assay was developed to quantify the virus. This was performed by targeting a highly conserved gene known as DNA polymerase (DPOL) gene using constructed plasmid as a standard curve calibrator. The obtained results showed an infection frequency of $33 \%$ in which the EHV-2 load reached 6647 copies/100 ng DNA whereas the minimum load revealed as 2 copies/100 ng DNA. The median quantification was found as 141 copies/ $100 \mathrm{ng}$ DNA. Establishment of a credited qPCR assay to quantify EHV-2 could be helpful in the control of the disease.
\end{abstract}

Keywords: qPCR, Gamma-herpesvirus, EHV-2, DPOL gene

DOI: 10.33899/ijvs.2019.126076.1229, (@2020, College of Veterinary Medicine, University of Mosul.

This is an open access article under the CC BY 4.0 license (http://creativecommons.org/licenses/by/4.0/).

تطوير تقتية تفاعل البلمرة المتسلسل الكمي (المحلي) للكثف عن فايروس هربس الخيول النمط الثاني

$$
\text { فرع الطب الباطني والوقائي، كلية الطب البيطري، جامعة القادية، القادسية، العراق السعدي }
$$

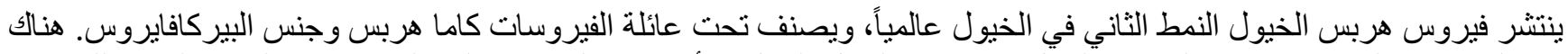

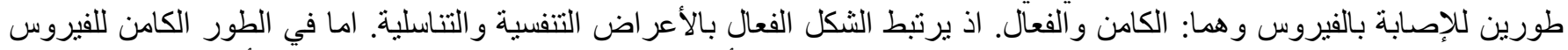

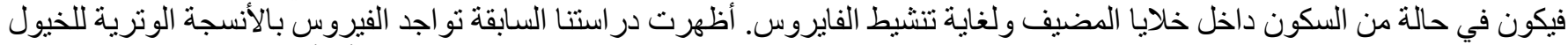

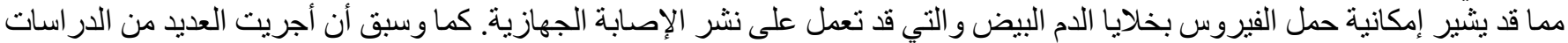

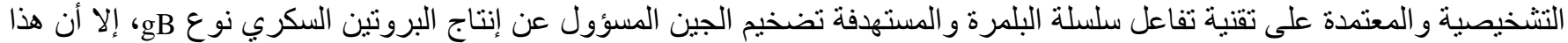

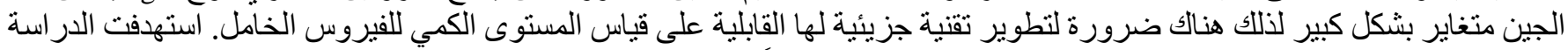

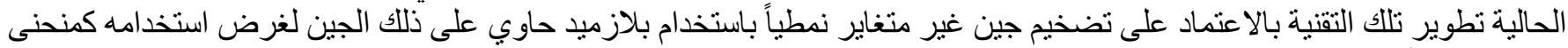

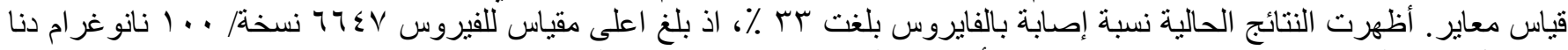

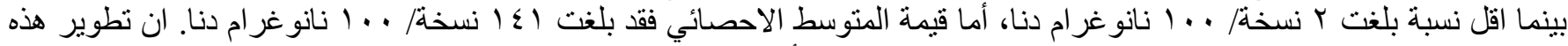
التقنية الكمية لقياس نسبة فايروس هربس الخيول النمط الثاني ممكن أن تساعد في السيطرة الأية على المرض. 


\section{Introduction}

Equine herpesvirus 2 (EHV-2) is a globally distributed viral disease of horses (1). It is a member of the family Herpesviridae, within gamma-herpesvirinae subfamily and percavirus genus (2). EHV-2 is an enveloped double stranded genomic DNA virus, $184,427 \mathrm{~kb}$ in size (2). To date, there are five herpesviruses infecting horses. These have been categorised within either alpha-herpesvirinae including: EHV-1, 3, and 4 species or gamma- herpesvirinae involving: EHV-2 and 5 species (1). EHV-2 co-infection with EHV-5 is commonly occurred (3). This co-infection was also demonstrated with an alpha-herpesvirus (EHV-1) in some abortion cases (4).

Like other herpesviruses, EHV-2 has two forms: latent and clinical infections. Commonly, young foals infected by the persistence phase with intermittent viral reactivations whereas adult horses mostly harbour the virus as a reservoir host thus likely play a role for viral spreading (5). This occurs according to host immunity (6). In most asymptomatic cases, EHV-2 has been detected from the respiratory and genital tissues $(3,7)$. In the clinically infected horses that suffer from respiratory, genital, and ocular signs, EHV-2 was identified in the relevant tissues of these cases (8-10). Our previous study has showed that EHV-2 can be harboured by equine tendons (11), suggesting that the peripheral blood mononuclear cells (PBMCs) possibly act as the source for the systemic viral dissemination. EHV-1 has been diagnosed in aborted mares in Iraq (12). Therefore, it can be assuming that EHV-2 may have a role in these infections.

There are numerous PCR techniques have been developed by targeting glycoprotein B gene; this gene is heterogenic, meanwhile, establishment of a PCR assay targeting this gene makes it restricted to a certain strain. Therefore, there is a need to develop a universal quantitative approach to detect the latent phase of infection. To achieve this, Taqman qPCR assay was developed to quantify EHV2. This was performed by targeting a highly conserved gene known as DNA polymerase (DPOL) gene. Moreover, EHV2 has not been quantified in Iraq which means that there is an urgent need to quantify the virus in this country. Additionally, it was found that B lymphocytes carry quiescent EHV-2 (13), suggesting that buffy coat sampling likely a suitable way to conduct the current study.

\section{Materials and methods}

\section{Sample material and DNA processing}

One hundred blood samples of healthy local horses Equus feruscaballus from different ages and sexes were obtained aseptically and collected into EDTA tubes and kept in ice until further laboratory work. These were then centrifuged at $4000 \mathrm{rpm}$ for 5 minutes. The separated buffy coats were isolated by pipetting and processed for DNA extraction using QIAamp DNA tissue and blood kit (Qiagen, 69504) according to the manufacturer's recommendation. For cell lysing, proteinase $\mathrm{k}$ was added meanwhile the lysates were transferred onto the DNeasy mini spin column then spun for DNA binding. The DNA was washed and eluted by the supplied reagents and kept at -20 until further laboratory work.

\section{Primers and probes design for Taqman qPCR}

Primers and probe were designed manually including the commercial fluorescent and quencher; as following: forward primer 5' CCA TCA AGG TCA CCT GCA AC 3'; reverse primer 5' CCC TCT ATG TAG CGC TTG GA 3'; and probe 5' FAM CCA GCA TGC GCC TGC CCT GG 3' TAMRA. These to amplify a highly conserved sequence known as DPOL gene of the EHV-2 (accession number KY401163.1). As a positive control for DNA quantification accuracy and normalization, the actin beta (ACTB) gene specific for (Equus caballus) (accession number NM 001081838.1) was also amplified under the same laboratory conditions with the following primers and probe: forward 5, AATCGTGCGTGACATCAAGG 3'; Reverse 5' CAG CTC GTA GCT CTT CTC CA 3'; Probe 5' VIC CCA CCG CGG CCT CCA GCT CT 3' MGBNFQ. All the primers and probes were supplied lyophilized (applied biosystem, UK) which then diluted to working concentration of $20 \mathrm{pmol} / \mu \mathrm{l}$ and kept at -20 in the dark condition until being used $(14,15)$.

\section{The qPCR optimal conditions}

Our previous work has resulted in construction of a reference plasmid containing DPOL gene that had been cloned via 3' adenine-overhangs into the pCR 2.0-TOPO vector (Invitrogen, UK) (11). This was called TOPO-EHV2. Similar protocol was followed for TOPO-ACTB. Herein, the both standards were measured by Qubit fluorimeter (Invitrogen, UK) meanwhile the required standard concentrations were calculated according to the following formula; Number of copies/ $\mu \mathrm{l}=$ (DNA (ng/ $\mu \mathrm{l}) \quad \mathrm{x}$ $\left(\left(6.022 \times 10^{23}\right) /(\right.$ length $\left.\times 650)\right)(16-18)$. The sensitivity of the assay was calibrated to start from $1 \times 10^{7}$ to $1 \times 10^{0}$ copies.

The reaction mixture in a total volume $20 \mu \mathrm{l}$, consists of $7 \mu \mathrm{l}$ of $2 \mathrm{x}$ TaqMan $^{\circledR}$ universal PCR master mix (applied biosystem, UK); the primers and probes were at concentration of $0.5 \mathrm{pmol} / \mu \mathrm{l}$. The optimal annealing temperature of primers and probes were determined in this study as $60^{\circ} \mathrm{C}$ by means of gradient protocol (Opticon machine, USA). Therefore, the optimal cycling temperature profile was performed as $50^{\circ} \mathrm{C}$ for $2 \mathrm{~min}$ as initial temperature followed by $13 \mathrm{~min}$ of $95^{\circ} \mathrm{C}$ then 39 cycles of $95^{\circ} \mathrm{C}$ for $15 \mathrm{sec}$, finally, $1 \mathrm{~min}$ of the optimal annealing temperature as mentioned above. The variation values of the assay's repeatability and reproducibility were analysed by carried out five independent runs for the TOPO-EHV2 in tenfold serial dilutions, in duplicates. The quantification data 
was analysed by means of GraphPad prism statistical software. All these procedures were conducted according to MIQE guidelines with statistics including mean value, mean of $\mathrm{r}^{2}$ and standard error of means $(14,19)$.

\section{Agarose gel electrophoreses}

A $1.5 \%$ of agarose gel was prepared by dissolving $1.5 \mathrm{~g}$ of agarose with $100 \mathrm{ml}$ of $1 \mathrm{x}$ TAE buffer then $10 \mu \mathrm{l}$ of fluorescent nucleic acid SYBR Safe gel stain (Invitrogen, UK) was added and mixed gently. The gel was poured into the electrophoreses tray that contains the appropriate comb and left to set 30 minutes. The DNA samples were loaded in the prepared gel cassette and electrophoresed in $1 \mathrm{x}$ TAE running buffer at $100 \mathrm{~V}$ for about 40 minutes. Finally, visualized by gel documentation (BioRad, USA).

\section{Results}

\section{Assay validation and limit of detection}

The validation of the sensitivity results for the TOPOEHV2 calibrator are depicted in (Figure 1.1) that was generated from conducting five qPCR runs. This revealed the mean value of the coefficients of determination as 0.996 with standard error of 0.003 .

The lowest mean value of the cycle threshold $(\mathrm{Cq})$ was showed as $11.72 \pm 0.28$ in the standard concentration of $1 \times 10^{7}$ copies whereas the highest mean value exhibited as $32.09 \pm 0.15$ in the standard concentration of $1 \times 10^{7}$ copies. The tenfold concentration of TOPO-EHV2 was being amplified successfully as single bands $136 \mathrm{bp}$, as shown in (Figure 1.2), all concentrations were revealed without nonspecific amplicons. However, expectedly, a very faint band was determined in the lower concentrations $1 \times 10^{1}$ and $1 \times 10^{0}$ copies).

\section{EHV-2 quantification}

The established quantitative assay was used to analyse the frequency and load of EHV-2 in DNA samples. This was carried out by designing specific primers and probes to amplify DPOL gene by an optimal protocol. This was also validated by amplifying the ACTB as an internal reference gene. Thus, all the quantification data was normalized and obtained from a similar amount of DNA template $100 \mathrm{ng}$ (Figure 2). EHV-2 was detected in $33 \%$ of the tested samples, in which $22 \%$ was determined in age $>5$ years while the remaining percentage was in age between 2-4 years. The infection percentage in the female was $19 \%$ which was exhibited more than male as $11 \%$.

Importantly, as can be seen in (Figure 3), viral load was found in high frequency with peak load of 6647 copies/100 ng DNA. The median viral load was quantified as 141 copies/ 100 ng DNA.

However, the minimum load was noticed as 2 copies/ 100 ng DNA. Quantifying the equine internal gene (ACTB) revealed minimum load 9575 copies / 100 ng DNA while the maximum value was $3.3 \times 106$ copies/100 ng DNA.
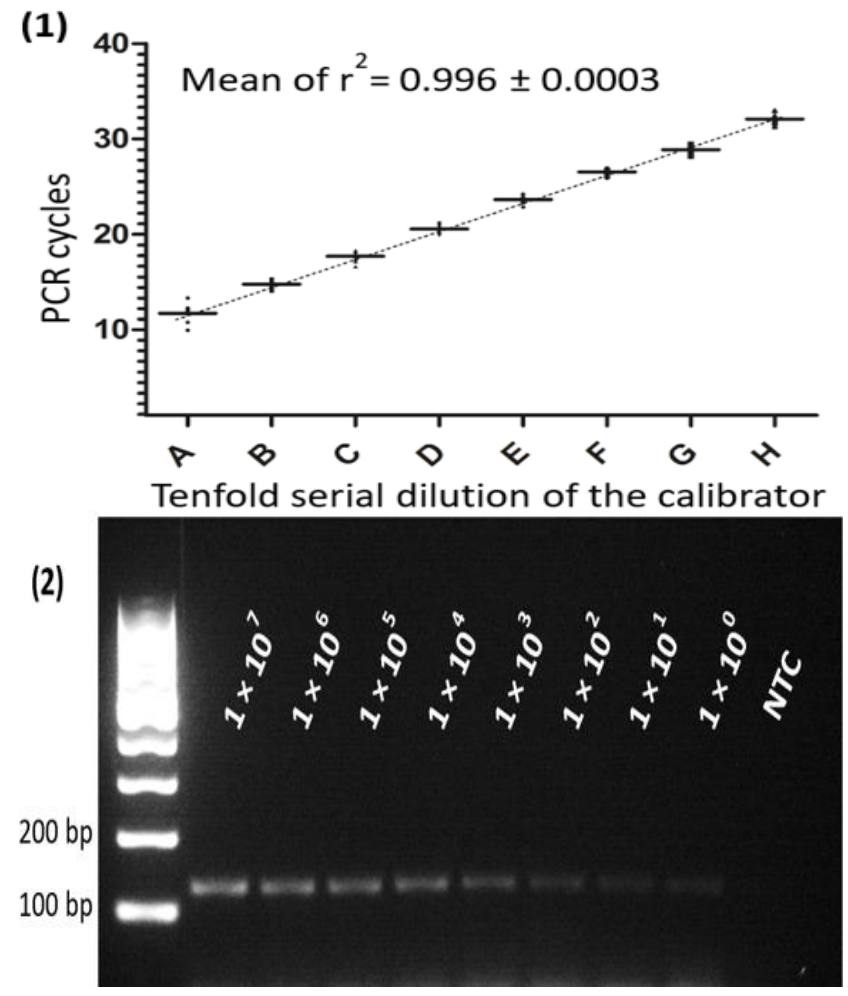

Figure 1: (1) Repeatability and reproducibility precisions of the standard calibrator that was employed to quantify EHV2 ; (-) indicates the mean of the $C q$ value generated by performing five individual qPCR experiments. Mean values were found significantly different $(\mathrm{P}<0.05)$ with $\mathrm{r}^{2}=0.996 \pm$ 0.0003 (analyzed by one-way ANOVA). (2) Gel electrophoreses $(1.5 \%)$ image shows the amplification of the tenfold serial dilution of the standard calibrator $(\mathrm{A}-\mathrm{H})$ (amplicon size $=136 \mathrm{bp})$. Abbreviation $\left(\mathrm{A}=1 \times 10^{7}, \mathrm{~B}=1 \times\right.$ $10^{6}, \mathrm{C}=1 \times 10^{5}, \mathrm{D}=1 \times 10^{4}, \mathrm{E}=1 \times 10^{3}, \mathrm{~F}=1 \times 10^{2}, \mathrm{G}=1 \times$ $10^{1}$, and $\mathrm{H}=1 \times 10^{0}$ copies respectively, $\mathrm{NTC}=$ no template DNA as a control negative).

\section{Discussion}

PCR technique allows researchers to detect infectious agents with high sensitivity and specificity. Recently, this molecular approach has been developed significantly. Therefore, several evolutionary and epidemiological viral studies have been performed due to the merits of reliability and applicability. This occurs through detection of viral DNA in a short period of time with less laborious. Nevertheless, this technique has some limitations such as DNA contamination, poor sample preparations, and importantly heterogeneity of the targeted gene $(14,20-22)$. 

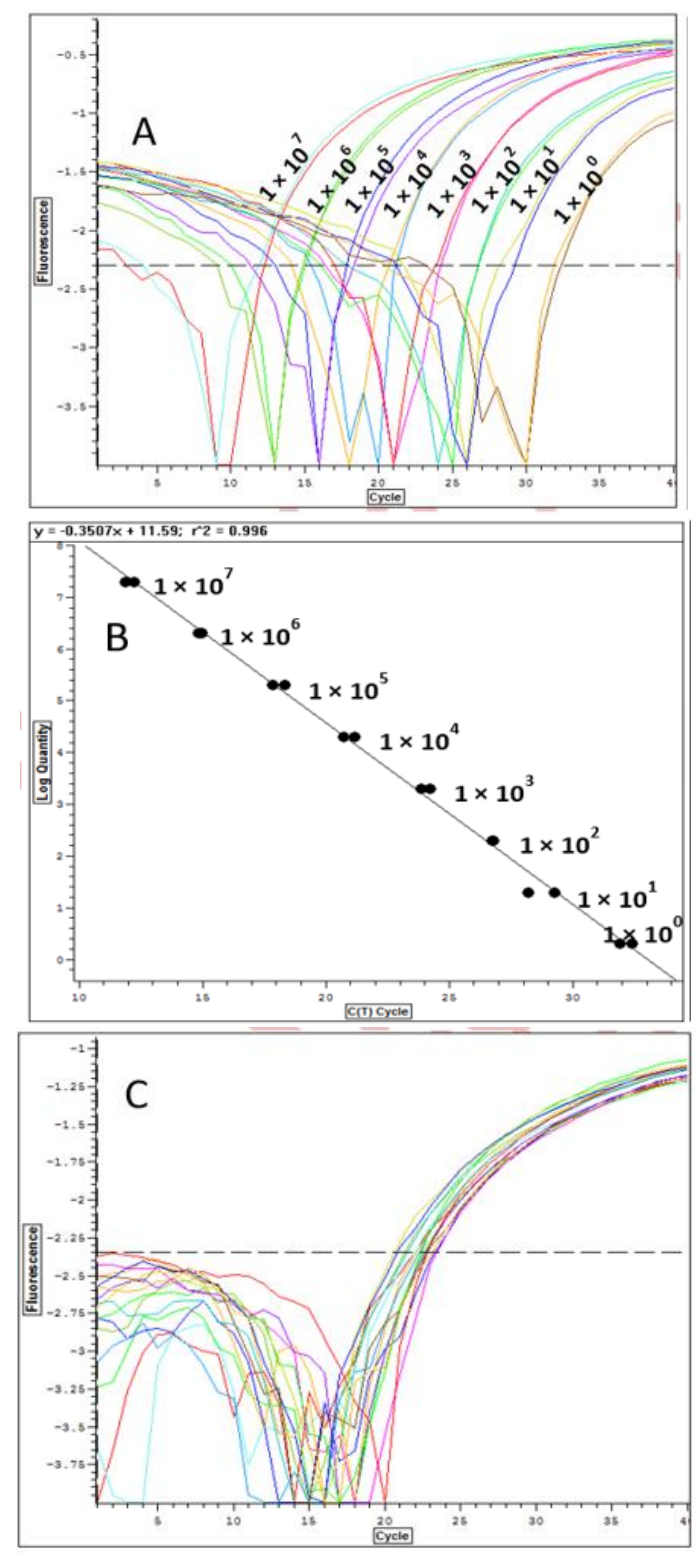

Figure 2: One qPCR experiment, as an example, shows (A) amplification curve of the assay. This was performed on serial ten-fold dilutions of the calibrator DNA. Duplicates were used for each dilution in which the $\mathrm{Cq}$ values were determined. These values depict the duplicates as tight and overlaid perfectly indicating low technical variability. (B) standard curve measured by $\mathrm{Cq}$ values that are plotted against the $\log$ of the standard calibrator. This allows us to calculate the $r 2$ value $\left(r^{2}=0.996\right)$. (C) amplification of ACTB gene as an internal genomic control gene, demonstrating highly similar amounts of template DNA 100 $\mathrm{ng} / \mu \mathrm{l}$. This was carried out to account the errors in the assay quantification and reaction efficiency resulted from DNA quality and contamination.

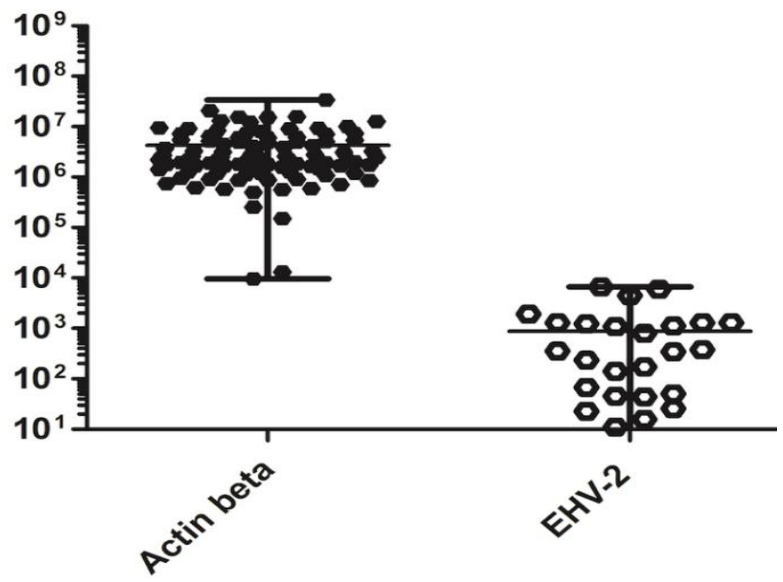

Figure 3: Quantification of the equine internal reference gene and EHV-2 loads. This statistical plot depicts a normal frequency distribution of quantifying both genes amplified from $100 \mathrm{ng}$ template DNA

Our previous study has showed that EHV-2 can be harboured by equine tendons (11). Thus, the PBMCs possibly have a role in the systemic viral dissemination. Similar to other gamma herpesviruses, EHV-2 establishes latent infection efficiently for long life period of time. It was found in these cell types by Borchers et al. (23). Little is known about EHV-2 in Iraq. Therefore, quantifying this virus would be helpful for epidemiologists in order to control the disease. Additionally, it was decided to examine the equine white blood cells in order to demonstrate the quiescent EHV-2 infection. To achieve this, we established a quantitative assay using credited standard curve (calibrator).

The obtained data generated by performing five qPCR runs, to validate the standard calibrator, revealed an efficient amplification results with a sensitivity started from $1 \times 10^{7}$ to $1 \times 10^{0}$ copies. This was analyzed statistically and demonstrates a coefficient of determination value as $0.996 \pm$ 0.003 . The efficiency of the template DNA was examined by amplifying actin beta internal gene as a positive control. As can be seen in (figure 3), the quantification data showed a normal distribution value. All these data are acceptable according to the MIQE guideline (14). This allows us to use it in quantifying the frequency of EHV-2 in the latent phase of disease.

Of interest, EHV-2 was found in 33\% of the tested samples in which $22 \%$ was determined in age $>5$ years whereas only $8 \%$ was detected in the age between 2-4 years. The infection percentage in the female was $19 \%$ which was exhibited more than male as $11 \%$. The relationship between infection and age or gender cannot be precisely determined here because other factors likely have a role to interplay with getting the infection. Therefore, other study should be 
designed including demonstration of certain farming conditions with involvement of animal case history. Furthermore, vertical viral transmission must be figured out prior to perform such a study. More importantly, EHV-2 load was demonstrated in latently infected horses as it varied from 2- 6647 copies/100 ng DNA with a median value of 141 copies/ 100 ng DNA. Finding EHV-2 in buffy coat was previously achieved by Wilks and Studdert (24). Precisely, it has been reported that EHV-2 is harboured by B lymphocytes (13). Additionally, EHV-2 was detected from symptomatic and asymptomatic horses, different ages, and various organs such as respiratory, ocular, uterus, placenta, aborted foetus, blood cells, digestive tissue and tendons (3,711,25-28). All these findings agree with our data of identifying latent EHV-2. Our result implies that EHV-2 perhaps recruit host WBCs efficiently in order to disseminate systemically. Suggesting that choosing the buffy coat sampling is an efficient way to perform any molecular or epidemiological detection of EHV-2.

Serological diagnosis of EHV-2 infection is relatively unreliable because of the antigenic relationship with EHV-5. Therefore, a specific serological discrimination between these two viruses seems to be weak $(1,29)$. Isolation of EHV2 via cell culturing system is achievable. However, it needs much laboratory efforts, extensive precautions, more time consumption and costly. Thus, numerous studies have been conducted to detect EHV-2 by employing PCR approach as a highly sensitive, more convenient, and applicable technique such as (7,31-35). Nevertheless, most of these studies were being conducted through targeting the gB gene. The genetic heterogeneity in this gene has been revealed by some researchers like Lee and Lee; Radalj et al; Ataseven et al. $(7,36,37)$. This genetic polymorphism was found in a low level though. Nevertheless, it could be associated with the age of the foals due to viral host interaction (38). Meanwhile targeting this gene for PCR is not ideal because of heterogeneity. Thus, the previously developed assays cannot be used globally due to various EHV-2 strains. Therefore, our technique was designed to amplify a highly conserved gene DPOL among all herpesviruses. This gene was being targeted to diagnose and differentiate wide range of herpesvirus species as well as investigating novel members $(39,40)$. Therefore, it is likely to be useful in detecting different EHV-2 strains even in the latent phase of infection.

EHV-2 is distributed in horses globally. This could be due to the fact that the virus has an efficient tactics to transmit horizontally (1). The respiratory excretion seems to be the main route to spread the infection since early age $(5,35)$.

Herein, the frequency of EHV-2 was detected in 33\% which is lower than the percentage in Turkey 59\% (41), Algeria 90\% (42), and France 50\% (28) whereas our data is comparable with those obtained by Azab et al. (43) in Egypt as the percentage was $38 \%$. However, these studies have been performed by examination of different sample types such as respiratory or genital tissues and this could explain the discrepancies with our data. Also, the geographical and control programme or other factors possibly still reasons. Herein, we used the absolute quantification qPCR assay with an internal reference gene (standard curve). To best of our knowledge, this is the first description of EHV-2 quantification in Iraq. Moreover, finding EHV-2 in local horses could explain numerous unknown abortion cases in mares. Further study is needed to investigate the equine herpesvirus co-infection and genetic multiallelic variation of EHV-2 in Iraq. In particular, screening the genetic heterogeneity of $\mathrm{gB}$ sequence. Development of this technique may be helpful for the epidemiologists in order to control EHV-2 infection.

\section{Conclusions}

Equine herpesvirus-2 has a quiescent form of infection in horses in which respiratory and genital are the main symptoms during EHV-2 reactivation. Therefore, the current assay will provide a suitable strategy to demonstrate this aspect. Thus, further study is required to define the pathological role of this virus. This study concludes that the DPOL gene likely a suitable target for the molecular detection of EHV-2 not only by the qPCR but also with conventional PCR. The current results could help in EHV-2 control in the future.

\section{Acknowledgement}

I would like to express my thanks to the technicians in the veterinary hospital of Al-Qadisiyah city for assisting me in collection of the blood samples. Also, the laboratory staff in the Molecular Virology/ University of Liverpool for providing the constructed plasmids as a standard calibrator to develop the currant assay. Finally, the Ministry of Higher Education and Scientific Research in Iraq for supporting me financially.

\section{Conflict of interest}

The author confirms that there is no conflict of interest in conducting this scientific work.

\section{References}

1. Fortier G, van Erck E, Pronost S, Lekeux P, Thiry E. Equine gammaherpesviruses: Pathogenesis, epidemiology and diagnosis. Vet J. 2010;186(2):148-56. Doi: 10.1016/j.tvj1.2009.08.017

2. Davison AJ. Herpesvirus systematics. Vet Microbiol. 2010;143(1):5269. Doi: $10.1016 /$ j.vetmic.2010.02.014

3. Dall AM, Beuttemmuller EA, Pilz D, Leme RA, Saporiti V, Headley SA. Detection of equid gammaherpesvirus 2 and 5 DNA in the upper respiratory tract of asymptomatic horses from southern Brazil. 
Brazilian J Microbiol. 2019;50(3):875-8. Doi: 10.1007/s42770-019$\underline{00100-7}$

4. Marenzoni ML, Bietta A, Lepri E, Casagrande Proietti P, Cordioli P, Canelli E. Role of equine herpesviruses as co-infecting agents in cases of abortion, placental disease and neonatal foal mortality. Vet Res Commun. 2013;37(4):311-7. Doi: 10.1007/s11259-013-9578-6

5. Hartley CA, Dynon KJ, Mekuria ZH, El-Hage CM, Holloway SA, Gilkerson JR. Equine gammaherpesviruses: Perfect parasites? Vet Microbiol. 2013;167(1-2):86-92. Doi: 10.1016/j.vetmic.2013.05.031

6. Muscat KE, Padalino B, Hartley CA, Ficorilli N, Celi P, Knight P. Equine Transport and Changes in Equid Herpesvirus' Status. Front Vet Sci. 2018;5:1-10. Doi: 10.3389/fvets.2018.00224/full

7. Lee SK, Lee I. The Molecular detection of equine herpesviruses 2 and 5 in genital swabs from clinically normal thoroughbred mares in south Korea. J Equine Vet Sci. 2019;79:68-72. Doi: 10.1016/j.jevs.2019.05.013

8. Hollingsworth SR, Pusterla N, Kass PH, Good KL, Brault SA, Maggs DJ. Detection of equine herpesvirus in horses with idiopathic keratoconjunctivitis and comparison of three sampling techniques. Vet Ophthalmol. 2015;18(5):416-21. Doi: 10.1111/vop.12250

9. Seval B; Babaoğlu D. Determination of presence of equid alpha and gammaherpesvirus infections in foals with respiratory distress. Ankara Üniversitesi Vet Fakültesi Derg. 2018;65(1):63-8. 10.1501/Vetfak_0000002828

10. Marenzoni ML, Sforna M, Stefanetti V, Casagrande Proietti P, Brignone L, Del Sero A. Detection of Equid herpesvirus type 2 and 5 DNA in uterine flushings of mares with reproductive disorders. Vet Microbiol. 2014;174(3-4):570-6. Doi: 10.1016/j.vetmic.2014.09.025

11. Wardle R, Pullman JA, Haldenby S, Ressel L, Pope M, Clegg PD. Identification of Equid herpesvirus 2 in tissue-engineered equine tendon. Welcome Open Res. 2017;2(0):60.

12. Al-Ajeeli SA. Molecular detection of equine herpes virus-1 in local horses (Equus feruscaballus) and donkeys (Equus asinus). Iraqi J Vet Med. 2018;42(1):72-8 doi: 10.30539/iraqijvm.v42i1.34

13. Drummer HE, Reubel GH, Studdert MJ. Equine gammaherpesvirus 2 (EHV2) is latent in B lymphocytes. Arch Virol. 1996;141(3-4):495504. Doi: $10.1007 / \mathrm{BF} 01718313$

14. Biassoni R, Walker JM. Quantitative real-time PCR. New York: Springer; 2014. 5-18 p. Doi: 10.1007/978-1-4939-0733-5

15. Rodriguez, A., Rodriguez, M., Cordoba, J., Andrade, M., 2015. Design of primers and probes for quantitative real-time PCR methods, in: Basu, C. (Ed.), PCR primer design. Springer, New York, pp. 31-56. https://doi.org/10.1007/978-1-4939-2365-6-3

16. Dhanasekaran S, Doherty TM, Kenneth J. Comparison of different standards for real-time PCR-based absolute quantification. J Immunol Methods. 2010;354(1-2):34-9. Doi: 10.1016/j.jim.2010.01.004

17. Godornes C, Leader BT, Molini BJ, Centurion-Lara A, Lukehart SA. Quantitation of rabbit cytokine mRNA by real-time RT-PCR. Cytokine. 2007;38(1):1-7. Doi:10.1501/Vetfak_0000002828

18. Hue ES, Fortier CI, Laurent AM, Quesnelle YF, Fortier GD, Legrand LJ. Development and validation of a quantitative PCR method for equid herpesvirus-2 diagnostics in respiratory fluids. J Vis Exp. 2016;17(109):1-13. doi:10.3791/53672

19. Taylor S, Wakem M, Dijkman G, Alsarraj M, Nguyen M. A practical approach to RT-qPCR-Publishing data that conform to the MIQE guidelines. Methods. 2010;50(4): S1-5. Doi: 10.1016/j.ymeth.2010.01.005

20. Domingues L. PCR. New York: Springer; 2017. 101-112 p. Doi: 10.1007/978-1-4939-7060-5

21. García-Arroyo L, Prim N, Martí N, Roig MC, Navarro F, Rabella N. Benefits and drawbacks of molecular techniques for diagnosis of viral respiratory infections. Experience with two multiplex PCR assays. J Med Virol. 2016;88(1):45-50. Doi: 10.1007/978-1-4939-7060-5

22. van Pelt-Verkuil E, van Belkum A, Hays JP. Principles and technical aspects of PCR amplification. Dordrecht: Springer; 2008. P 10091010. Doi: 10.1007/978-1-4020-6241-4
23. Borchers K, Wolfinger U, Goltz M, Broll H, Ludwig H. Distribution and relevance of equine herpesvirus type 2(EHV-2) infections. Arch Virol. 1997;142(5):917-28. Doi: 10.1007/s007050050128

24. Wilks CR, Studdert MJ. Equine herpesviruses: 5. Epizootiology of slowly cytopathic viruses in foals. Aust Vet J. 1974;50(10):438-42. Doi: 10.1111/j.1751-0813.1974.tb06866.x

25. Pennington MR, Cossic BGA, Perkins GA, Duffy C, Duhamel GE, Van de Walle GR. First demonstration of equid gammaherpesviruses within the gastric mucosal epithelium of horses. Virus Res. 2017;242(August):30-6 Doi: 10.1016/j.virusres.2017.09.002

26. Negussie H, Gizaw D, Tesfaw L, Li Y, Oguma K, Sentsui H. Detection of Equine Herpesvirus (EHV) -1, -2, -4 and -5 in ethiopian equids with and without respiratory problems and genetic characterization of EHV2 and EHV-5 strains. Transbound Emerg Dis. 2017;64(6):1970-8. Doi: 10.1111/tbed.12601

27. Back H, Ullman K, Treiberg BL, Riihimäki M, Penell J, Ståhl K. Viral load of equine herpesviruses 2 and 5 in nasal swabs of actively racing Standardbred trotters: Temporal relationship of shedding to clinical findings and poor performance. Vet Microbiol. 2015;179(3-4):142-8. Doi: $10.1016 /$ j.vetmic. 2015.06 .002

28. Hue ES, Fortier GD, Fortier CI, Leon AM, Richard EA, Legrand LJ. Detection and quantitation of equid gammaherpesviruses (EHV-2, EHV-5) in nasal swabs using an accredited standardised quantitative PCR method. J Virol Methods. 2014;198:18-25. Doi: 10.1016/j.jviromet.2013.12.008

29. Telford EAR, Studdert MJ, Agius CT, Watson MS, Aird HC, Davison AJ. Equine Herpesviruses 2 and 5 Are $\gamma$-Herpesviruses. Virology. 1993;195(2):492-9 Doi: 10.1006/viro.1993.1400

30. Borchers K, Wolfinger U, Goltz M, Broll H, Ludwig H. Distribution and relevance of equine herpesvirus type 2 (EHV-2) infections. Arch Virol. 1997;142(5):917-28. Doi: 10.1007/s007050050128

31. Franchini M, Akens M, Bracher V, Fellenberg R V. Characterisation of gamma herpesviruses in the horse by PCR. Virology. 1997;238(1):8-13 Doi: 10.1006/viro.1997.8825

32. Nordengrahn A, Merza M, Ros C, Lindholm A, Plfi V, Hannant D. Prevalence of equine herpesvirus types 2 and 5 in horse populations by using type-specific PCR assays. Vet Res. 2002;33(3):251-9. Doi: 10.1051/vetres:2002013

33. Reubel GH, Crabb BS, Studdert MJ. Diagnosis of equine gammaherpesvirus 2 and 5 infections by polymerase chain reaction. Arch Virol. 1995;140(6):1049-60. Doi: 10.1007/BF01315414

34. Sharp EL, Farrell HE, Borchers K, Holmes EC, Davis NJ. Sequence analysis of the equid herpesvirus 2 chemokine receptor homologues E1, ORF74 and E6 demonstrates high sequence divergence between field isolates. J Gen Virol. 2007;88(9):2450-62. Doi: 10.1099/vir.0.82942-0

35. Torfason EG, Thorsteinsdóttir L, Torsteinsdóttir S, Svansson V. Study of equid herpesviruses 2 and 5 in Iceland with a type-specific polymerase chain reaction. Res Vet Sci. 2008;85(3):605-11.

36. Radalj A, Nišavić J, Krnjaić D, Valčić M, Jovanović T, Veljović L. Detection and molecular characterization of equine herpesviruses 1,2, and 5 in horses in the republic of Serbia. Acta Vet Brno. 2018;87(1):2734 Doi: 10.2754/avb201887010027

37. Ataseven VS, Bilge-Dagalp S, Oguzoglu TÇ, Karapinar Z, Güzel M, Tan MT. Detection and sequence analysis of equine gammaherpesviruses from horses with respiratory tract disease in turkey. Transbound Emerg Dis. 2010;57(4):no-no. Doi: 10.1111/j.1865-1682.2010.01146.x

38. Brault SA, Bird BH, Balasuriya UBR, MacLachlan NJ. Genetic heterogeneity and variation in viral load during equid herpesvirus-2 infection of foals. Vet Microbiol. 2011;147(3-4):253-61. Doi: 10.1016/j.vetmic.2010.06.031

39. Vandevanter DR, Warrener P, Bennett L, Schultz ER, Coulter S, Garber RL. Detection and analysis of diverse herpesviral species by consensus primer PCR. J Clin Microbiol. 1996;34(7):1666-71.Doi: DOI: 10.1128/JCM.34.7.1666-1671.1996

40. Ehlers B, Borchers K, Grund C, Frölich K, Ludwig H, Buhk HJ. Detection of new DNA polymerase genes of known and potentially 
novel herpesviruses by PCR with degenerate and deoxyinosinesubstituted primers. Virus Genes. 1999;18(3): 211-20. DOI: 10.1023/a:1008064118057

41. Akkutay AZ, Osterrieder N, Damiani A, Tischer BK, Borchers K, Alkan F. Prevalence of equine gammaherpesviruses on breeding farms in Turkey and development of a TaqMan MGB real-time PCR to detect equine herpesvirus 5 (EHV-5). Arch Virol. 2014;159(11):2989-95. Doi: 10.1007/s00705-014-2165-5
42. Laabassi F, Hue E, Fortier C, Morilland E, Legrand L, Hans A. Epidemiology and molecular detection of equine herpesviruses in western Algeria in 2011. Vet Microbiol. 2017;207(1):205-9. Doi: 10.1016/j.vetmic.2017.06.017

43. Azab W, Bedair S, Abdelgawad A, Eschke K, Farag GK, AbdelRaheim A. Detection of equid herpesviruses among different Arabian horse populations in Egypt. Vet Med Sci. 2019; 31:176. Doi: $\underline{10.1002 / \mathrm{vms} 3.176}$ 